\title{
Modesty
}

AndréSimon

Korrespondenz: Dr. med. André Simon Dörflistrasse 14 CH-8057 Zürich andre.simon[at]hin.ch

\section{Cultivating rice}

In ancient times, a teacher of a crown prince had peculiar teaching methods. In his approach to all the virtues required of a future Emperor, the teacher used simply grains of rice as an object of his teaching. He held out a handful of rice to the crown prince. Studying rice production from the very begin of planting, ripening and harvesting until it becomes delicious boiled rice, «the one to be Emperor» was educated in life's supreme virtues like diligence, patience, and humility.

The cultivation of rice involves many activities before it reaches its final form of food. It involves ploughing the paddy fields, planting, harvesting, attentive care and a great deal of patience. The modest peasants know when it is time to plant their rice and wait patiently for its maturation. They humbly accept accidents and storms. From planting to harvesting of their rice, there are many stages in the feelings of humility. Working in cold water and mud, stooping down towards the ground, the peasants spread the rice plants.

While waiting patiently for their rice to ripen, the peasants form and strengthen their characters, and reach the virtue of maturity.

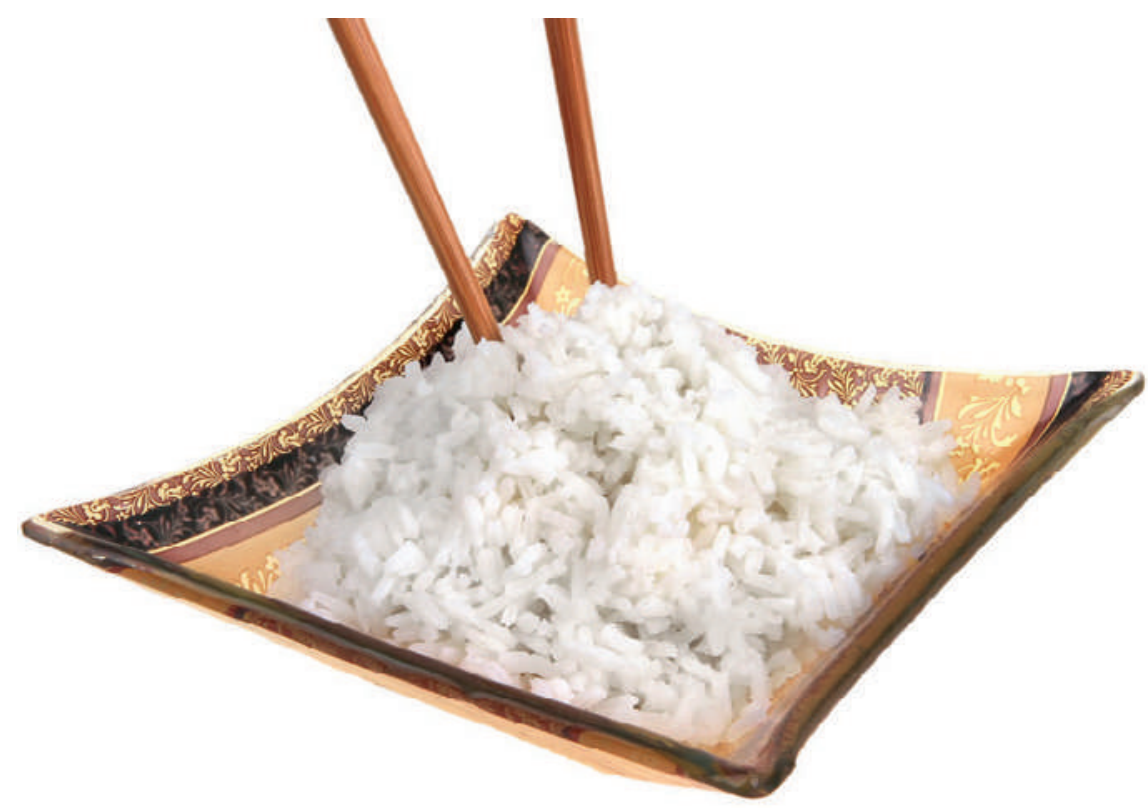

\section{Gardener's delight}

In the land of rice, the Emperors lived in unashamed luxury, but not the Emperor SHUN. His palace was very modest and ordinary, but his garden was exceptional, with scented flowers and many blossoming cherry trees, home for countless colourful songbirds. The merit was attributed to his Supreme Gardener. The Supreme Gardener lived in a modest bamboo fronted house with a small flower-garden. He had a daughter called Blossoming Violet ( 紫罗兰 zi ió-lán).

Her name was a distinguishing feature of her life, and a clear sign of her destiny. Delicate like a flowering violet, she showed appreciation and gratitude towards all living creatures.

Gardening brings man and nature together to create beauty. This amazing garden showed the marvellous art of Supreme Gardener, who became generally known as »the gardener who creates daydreams».

Every day his devoted daughter accompanied him to the Emperor's garden. There, she listened to the birds singing or played on her GUZSENG (zither) in the midst of scenting flowers. Her playing and her appearance pleased and enchanted everybody, even the Emperor, who with the passage of time decided to marry the daughter of his Supreme Gardener.

Like the flowers, the Empress Blossoming Violet had no interests outside the garden. There, she observed the birds, and noticed that some birds used small sticks to reach insects to eat. The insects usually hid under the bark of the trees. Holding a short stick or branch in their beaks, a bird would use it to probe into the fissure of a tree trunk to find an insect under the bark, and then peck it off to eat. After seeing that, the Empress proposed creating short wooden sticks to carry hot rice towards the mouth. Using them meant: no more burned fingers with hot rice.

And all subjects in the Empire started to the wooden chopsticks to enjoy their meals. It is known that chopsticks used in the court were made of decorated and engraved cherry-wood. The engravings described the gardener's daughter Blossoming Violet, who treated all beings with grace like the fragile flowers. 